DOI: https://doi.org/10.31392/NZ-npu-143.2019.19

УДК 378.016:364-051(477)

Павелків К. М.

\title{
РЕТРОСПЕКТИВНИЙ АНАЛІЗ ПІДГОТОВКИ МАЙБУТНІХ ФАХІВЦІВ СОЦІАЛЬНОЇ СФЕРИ В УКРАЇНІ
}

Сьогодні у світі зростає усвідомлення значущості соиіальної сфери в житті окремої людини, актуалізується соиіальна політика, зростає потреба в соџіальному захисті населення. Професійна підготовка фахівиів соиіальної сфери переживає складний період реформування, тому визначення правильної стратегії у розвитку сочіальної політики, конкретних напрямів $i$ сфер соиіальної роботи, системи підготовки кадрів для ијєєі сфери є для України сьогодні надзвичайно важливим питанням. Підготовка сочіальних працівників має свої особливості, які зумовлені специфікою процесу становлення порівняно нової професії в Україні, складністю й різноплановістю діяльності, труднощами працевлаштування спеціалістів, стереотипами у ставленні до фахівиів сочіальної сфери.

У статті здійснено иілісний хронологічний аналіз становлення професійної підготовки майбутніх фахівиів соиіальної сфери в Украӥні, на основі якого у иій підготовиі виокремлено й схарактеризовано три періоди: I період (1991 p.-2000 p.), II період (2001 p.-2010 p.), III період (2011 p. - по теперішній час). 3'ясовано, що у кожен з визначених періодів у контексті економічних і сочіальних умов професійна підготовка майбутніх фахівців соціальної сфери мала свої особливості. Доведено, що вивчення історії становлення і розвитку підготовки майбутніх фахівців сочіальної сфери, критичне осмислення соиіально-педагогічної практики допоможе уникнути помилок на сучасному етапі розвитку компетентності фахівия й максимально творчо використати накопичений досвід.

Ключові слова: майбутні фахівиі сочіальної сфери, соціальна робота, сочіальний працівник, сочіальний педагог, професійна підготовка.

Сучасна система вищої освіти України перебуває на шляху свого реформування та узгодження з кращими світовими зразками. Це пов'язано, насамперед, з підготовкою конкурентоспроможного фахівця, який може себе гідно представити світовому та європейському ринку праці. Це стосується і підготовки працівників соціальної сфери, позаяк у світі зростає усвідомлення значущості соціальної сфери в житті окремої людини, актуалізується соціальна політика, зростає потреба в соціальному захисті населення.

Для успішності процесів підготовки фахівців соціальної сфери в Україні величезне значення має вивчення, осмислення і адаптація як зарубіжного, так і вітчизняного досвіду такої підготовки в його історичній ретроспективі. Закономірно, що в процесі підготовки фахівців соціальної сфери враховується соціокультурна ситуація, реальний економічний та соціальний стан, адже власне ці чинники впливають і вирішальним чином впливатимуть на сутність соціальної і соціально-педагогічної діяльності у майбутньому і на систему вимог, що пред'являються до фахівців соціальної сфери. Професійна підготовка відповідних фахівців переживає складний період реформування, тому визначення правильної стратегії у розвитку соціальної політики, конкретних напрямів і сфрер соціальної роботи, системи підготовки кадрів для цієї сорери $\epsilon$ для України сьогодні 
надзвичайно важливим питанням.

Профресійна підготовка соціальних працівників $€$ актуальною проблемою і вимагає, з одного боку, розробки науково обґрунтованих вимог до програм професійної освіти, професійного відбору абітурієнтів, 3 другого - вивчення зарубіжного й вітчизняного досвіду підготовки фахівців у цій галузі задля ефективної й результативної підготовки майбутніх фрахівців у контексті викликів сучасності. Підготовка соціальних працівників має свої особливості, які зумовлені специфрікою процесу становлення порівняно нової професії в Україні, складністю й різноплановістю діяльності, труднощами працевлаштування спеціалістів, стереотипами в ставленні до фрахівців соціальної сфрери.

В усіх європейських країнах переважно використовується термін "фахівець соціальної сфери" стосовно тих спеціалістів, які професійно займаються допомогою людям. Відтак, і в Україні на сучасному етапі до фрахівців соціальної сорери стали відносити соціальних працівників, соціальних педагогів, спеціальних педагогів (логопеди, дефектологи) та психологів (практичні психологи). На сьогодні в Україні фрахівець соціальної сфери - це особа, яка переважно працює в закладах освіти (соціальний педагог) або в соціальних службах (допомога малозабезпеченим або неблагополучним сім'ям, проблемним дітям, ветеранам тощо), соціальних центрах та організаціях. Завдання фрахівця соціальної сфери допомога людині (будь-якої категорії), яка звернулася за допомогою до соціальних служб.

Оскільки, об'єктивно проаналізувати будь-яку проблему неможливо без знання історії, а критичне осмислення соціально-педагогічної практики допоможе уникнути помилок на сучасному етапі розвитку компетентності фрахівця і зважаючи на те, що в Україні досить своєрідно відбувався процес становлення означеної професії, вивчення історії становлення і розвитку підготовки майбутніх фрахівців соціальної сфрери вважаємо на часі.

Проблему підготовки майбутніх фахівців соціальної сфери (соціальних працівників, соціальних педагогів) досліджували Н. Басова, О.Безпалько, М. Богданова, І. Звєрєва, А. Капська, Л. Коваль, А. Мудрик, Р. Овчарова, С. Пальчевский, В. Поліщук, С. Савченко, С. Харченко та ін. [1; 4].

Сучасними вченими (Н.Гусак, Р.Вайнола, Н. Коляда, О. Кравченко, Ю. Швалб та ін.) здійснюється наукове обґрунтування змісту та ефективних технологій професійної підготовки соціальних працівників [6; 7].

Водночас, історія становлення й розвитку підготовки майбутніх фрахівців соціальної сфрери ще не отримала належного вивчення й узагальнення.

Mema cmammi - здійснити історичний аналіз становлення й розвитку підготовки майбутніх фахівців соціальної сфери в Україні.

Підготовка майбутніх фахівців соціальної сфери (соціальних педагогів і соціальних працівників) як окремий напрям професійної освіти і професійної діяльності почала формуватися на початку 1990-х років. До середини 1980-х років соціально-педагогічна підготовка перебувала в руслі загальної педагогічної. Партійні та комсомольські осередки визначали її завдання, контролювали виконання. В школах соціально-педагогічну діяльність виконували піонерські вожаті, організатори з позакласної та позашкільної виховної роботи і класні керівники, які не мали відповідної фрахової соціально-педагогічної 
підготовки [8].

Наприкінці 80-х років XX ст. професійна підготовка соціального педагога формується як цілісна система. У 1989 р. Державний комітет СРСР з народної освіти та Академія педагогічних наук СРСР створили на Донбасі тимчасовий науково-дослідний колектив “Школа-мікрорайон” під керівництвом В. Бочарової. Головними завданнями ТНДК “Школа - мікрорайон” були створення принципово нової концепції соціального виховання, яка передбачала б удосконалення позашкільного середовища, подолання духовної порожнечі у сфері побуту, сім'ї, дозвілля; моделювання єдиної системи виховання дітей і дорослих за місцем проживання. Дослідження ТНДК мали комплексний та міжвідомчий характер. У ньому брали участь, крім Міносвіти, Мінкультури, Держкомспорт, МBC, Всесоюзна федерація профспілок. Працювали 100 експериментальних площадок, 2 тисячі фахівців (серед них педагоги, фрілософи, соціологи, психологи, юристи, медики тощо), 25 закладів вищої освіти, 2500 колективів різноманітних закладів [9].

Результатом роботи тимчасового колективу стало обґрунтування нових професій “соціальний педагог”, "соціальний працівник”, розроблені професіограма та кваліфрікаційні характеристики соціальних педагогів, навчальні плани і програми їхньої професійної підготовки; створена Всесоюзна Асоціація соціальних педагогів та соціальних працівників; розпочате видання журналу "Соціальна робота" [8].

13 липня 1990 р. колегія Держкомітету СРСР з народної освіти прийняла рішення “Про запровадження інституту соціальних педагогів", а місяцем раніше (21.06.1990р.) було видано наказ "Про відкриття спеціальності "Соціальна педагогіка" для вищих і середніх спеціальних навчальних закладів". Відповідно до цього наказу були розроблені навчальні плани, які в грудні 1990 р. були розіслані в усі педагогічні навчальні заклади. Вже 23 квітня 1991 року Постановою Держкомпраці СРСР “Про доповнення в Кваліфікаційний довідник посад керівників, спеціалістів і службовців" кваліфікаційний довідник був поповнений кваліфікаційною характеристикою - "Спеціаліст із соціальної роботи", а колегією Державного комітету з питань науки і вищої школи було прийняте рішення "Про організацію підготовки кадрів з соціальної роботи у вузах". У цьому ж році Держкомітетом з освіти СРСР (наказ від 7 серпня 1991 р. № 376) було уведено спеціальність 03.11.00 "Соціальна педагогіка", що відобразилося у наборі абітурієнтів більш, ніж у тридцяти інститутах. Приміром, на теренах України підготовка таких спеціалістів розпочалася в Запорізькому державному університеті (Л. Міщик), а через рік - в Харківському інституті культури (Н. Бура), Донецькому державному університеті (В. Сидоров) [1, с. 51-52].

Відповідно до означених змін розроблялася нормативна база для введення в навчальних закладах спеціальностей "Соціальна педагогіка" та "Соціальна робота", була організована Українська Асоціація соціальних педагогів та спеціалістів із соціальної роботи (7 серпня 1992 року), вивчався зарубіжний досвід, велися власні творчі пошуки, наукові дискусії, готувалися практичні передумови для налагодження підготовки і підвищення кваліфікації фрахівців нового профрілю.

У 1992 р. в Донецькому університеті відкрито спеціальний фракультет перепідготовки соціальних педагогів і працівників; у 1993 р. в Національному університеті “Києво-Могилянська академія" було відкрито нову спеціальність - 
“соціальна робота" [2].

Важливу роль у становленні нової спеціальності відіграв україно-британопортугальський проект ТЕМПУС-ТАСІС “Соціальна робота в Україні”. Завдяки гранту Європейського Союзу до Школи соціальної роботи Києво-Могилянської академії, офріційно створеної у вересні 1994 р. й очолюваної Володимиром Полтавцем, приїхали відомі закордоні фрахівці (Шуламіт Рамон, Стівен Шардоу, Фернанда Родрігес та ін.), які викладали студентам і ділилися досвідом 3 українськими колегами, проводилися міжнародні науково-практичні конференції, відбувалося стажування студентів і викладачів за кордоном. Проект було підтримано на урядовому рівні, реалізація його дала змогу ввести нову спеціальність "соціальна робота" у перелік спеціальностей Міністерства освіти України [9, с. 106].

У межах україно-фрінсько-голландського проекту ТАСІС Європейського Союзу "Соціальний захист в Україні", який реалізовувався упродовж 1996-1998 рр., діяла робоча група та відбувалась розробка програми для підготовки фрахівців у Чернігівському юридичному коледжі, де ввели нову спеціальність із соціальної роботи на рівні молодшого спеціаліста (1997), а вже згодом на рівні бакалавра (1999).

У 1997-2000 роках в Україні діяв україно-шведський проект, метою якого було створення моделі підготовки соціальних працівників базового рівня (в декількох областях були проведені відповідні пілотні курси).

На базі кафедри соціальної роботи Ужгородського національного університету діяв україно-британо-бельгійський проект ТЕМПУС-ТАСІС щодо створення мережі навчальних закладів, які готують соціальних працівників.

У 90-і pp. XX ст. було започатковано наукові розробки із соціальної педагогіки й підготовку фахівців у Запорізькому державному університеті під керівництвом Л. Міщик [2]. Провідні вітчизняні педагоги створювали в інститутах та університетах (Київ, Донецьк, Харків, Запоріжжя, Одеса, Луганськ, Сімферополь, Тернопіль та ін.) кафедри соціальної педагогіки та соціальної роботи, розпочинали здійснювати фахову підготовку фахівців соціальної сфрери, організовували експериментальні соціально-педагогічні майданчики і т. п.

З 1997 р. почав виходити журнал “Соціальна політика і соціальна робота", пізніше - журнали "Практична психологія і соціальна робота", "Соціальна робота в Україні: теорія і практика". Міністерство праці та соціальної політики України випускає відомчі видання "Україна: аспекти праці”, “Охорона праці”, “Соціальний захист".

У 1999 р. у НаУКМА було започатковано підготовку магістрів за спеціальністю 8.040202 “Соціальна робота"; у цьому ж році Указом Президента України встановлено й професійне свято - День працівника соціальної сфрери (у першу неділю листопада).

Власне, саме з кінця XX ст. практична соціально-педагогічна діяльність у вітчизняній освіті та сорері соціальної роботи розпочала здійснюватися на законних засадах.

Правове й законодавче закріплення соціальної роботи як фаху в Україні відбулося завдяки ухваленню законів "Про соціальну роботу з дітьми та молоддю" (2001р.), "Про соціальні послуги" (2003р.), внесенню відповідних посад до державного класифікатора професій, розробленню стандартів надання 
соціальних послуг.

32002 р. в школах України було введено посаду “соціальний педагог”, що, відповідно, вимагало здійснення фрахової підготовки й таких фрахівців у вищій школі.

На сьогодні, статус фрахівців соціальної сфери (практичні психологи, соціальні педагоги) як педагогічних працівників гарантований ст.76 Закону України “Про освіту” (2017р.).

Постановою КМУ “Про перелік напрямів, за якими здійснюється підготовка фахівців у вищих навчальних закладах за освітньо-кваліфікаційним рівнем бакалавра" № 1719 від 13 грудня 2006 р. в галузь знань 1301 "Соціальне забезпечення" увійшло два напрями підготовки 6.130101 “Соціальна допомога” та 6.130102 "Соціальна робота" [5].

Відповідно до Наказу Міністерства соціальної політики України від 25. 05. 2012 р. за № 324 "Про затвердження нової редакції кваліфікаційної характеристики професії “Фахівець із соціальної роботи” були внесені зміни до завдань та обов'язків фахівця із соціальної роботи [3].

На сьогодні здобувачі відповідного ступеня вищої освіти галузі знань 23 "Соціальна робота" за напрямом підготовки 231 "Соціальна робота" опановують освітньо-професійні програми з різними спеціалізаціями: "Соціальна робота", “Соціально-психологічна реабілітація", “Соціальне забезпечення", "Соціально-психологічне консультування" тощо.

Відповідно до стандарту вищої освіти України (2016р.) підготовка на бакалаврському рівні за спеціальністю "Соціальна робота" передбачає певну кількість кредитів та спрямування половини обсягу освітньої програми на забезпечення формування у студента загальних і фрахових компетентностей; на магістерському рівні підготовка фахівців соціальної сфери спрямована на майбутню викладацьку та науково-практичну роботу й передбачає професійну діяльність за фахом в установах державного управління і соціального захисту .

Спеціальність стрімко набуває популярності: якщо у 90-х роках минулого століття підготовкою фахівців соціальної сфери займалися лише чотири заклади вищої освіти нашої країни, то станом на 2012 р. в Україні професійну підготовку соціальних працівників у системі вищої освіти здійснювало понад 30 державних та приватних навчальних закладів, а за даними 2017 р. за цією спеціальністю готують випускників 38 державних та 7 приватних закладів освіти.

Профресійна підготовка фахівців соціальної сфери детермінована соціальними, економічними і культурними умовами розвитку українського суспільства, що постійно змінюються й $є$ значущими для системи вищої освіти, а також принципами, які відображають специфіку соціальної діяльності у суспільстві. Тому перед соціальною освітою в Україні стоїть складне завдання збалансувати складну ситуацію сьогодення, поставивши в центрі уваги людину, зробивши на неї ставку, особливо людину, чиї безпека, життєвий рівень, права і благоустрій бажають значно кращого. I саме тут навчання соціальній роботі повинно відігравати провідну роль. Для вирішення цього завдання потрібен весь досвід, знання, які нагромаджені в нашій країні та в зарубіжних країнах, які необхідно творчо використовувати і розвивати.

Отже, в Україні професійна підготовка майбутніх соціальних працівників 
пройшла три періоди, які, за твердженням І. Б. Савельчук [7], були визначальними для її становлення та розвитку:

І період (1991 р.-2000р.) - відкриття нової для України спеціальності "Соціальна робота" за напрямом "Соціологія" та створення організаційних умов для забезпечення підготовки соціальних працівників, активна діяльність міжнародних організацій (україно-британо-португальський проект ТЕМПУС-ТАСІС "Соціальна робота в Україні", україно-фрінсько-голландський проект ТАСІС Європейського Союзу “Соціальний захист в Україні", проект Християнського дитячого фронду "Соціальна освіта в Україні”; створення Асоціації соціальних педагогів і працівників соціальної сфери, відкриття першого факультету перепідготовки соціальних педагогів і працівників у Донецькому університеті, перший набір майбутніх соціальних працівників у Запорізькому Університеті, Харківському інституті культури; поява україномовної фахової літератури, у тому числі періодичних видань, поява професійного свята - Дня працівника соціальної сорери;

II період (2001 p.-2010 р.) - створення правового й законодавчого підґрунтя соціальної роботи, становлення спеціальності "Соціальна робота" за напрямом "Соціальне забезпечення" та створення організаційно-методичних умов для відповідності підготовки соціальних працівників рівням європейської освітньої системи зі збереженням структури вітчизняної системи професійної освіти "молодший спеціаліст - бакалавр - спеціаліст - магістр"; ухвалення національного етичного кодексу і ратифікація міжнародної Декларації етичних принципів і стандартів соціальної роботи;

III період (2011р. - по теперішній час) - остаточне становлення спеціальності "Соціальна робота" за напрямом "Соціальна робота" та створення організаційно-методичних умов для оновлення підготовки фрахівців соціальної сорери відповідно до проблематики соціальної роботи; формується інноваційна підготовка фахівців соціальної сфери на основі компетентнісного підходу.

Висновки і перспективи подальших досліджень. Отже, ретроспективний аналіз підготовки майбутніх фахівців соціальної сфери в Україні дав змогу визначити й схарактеризувати три періоди, які були визначальними для їі становлення та розвитку, як-то: І період (1991 р. - 2000 р.), II період (2001 р. 2010 р.), III період (2011р. - по теперішній час). З'ясовано, що у кожен 3 визначених періодів у контексті економічних і соціальних умов професійна підготовка майбутніх фахівців соціальної сфери мала свої особливості.

Своєрідність сучасного стану підготовки майбутніх фахівців соціальної сфери в нашій країні значною мірою зумовлена особливостями соціальних процесів і профресійної освіти, оскільки професіоналізація соціальної роботи і соціальнопедагогічної діяльності та впровадження професійної освіти тих, хто їі здійснює, відбулися на початку 1990-х рр. директивним шляхом з метою модернізації соціальної сфрери за світовими стандартами, не зовсім враховуючи специфріку розвитку вітчизняної освіти і соціального забезпечення.

Перспективу подальших досліджень вбачаємо в обґрунтуванні можливості і доцільності використання зарубіжного досвіду підготовки фахівців соціальної сорери в умовах університетської освіти. 


\section{Використана література:}

1. Лукашевич М. П., Семигіна Т. В. Соціальна робота (теорія і практика) [Текст] : підручник. Київ : Каравела, 2009. 368 с.

2. Міщик Л. І. Соціальна педагогіка: досвід та перспективи. Запоріжжя, 1999. 248 с.

3. Наказ Міністерства соціальної політики України "Про затвердження нової редакції кваліфікаційної характеристики професії “Фахівець із соціальної роботи” від 25.05.2012 року № 324 [Електронний ресурс]. Режим доступу: http://romny-mcss.edukit.sumy.ua/Files/ downloads/наказ\%20Мінсоцполітики\%20 від\%2025.05.2012\%20№324.doc

4. Поліщук В. А., Янкович О. І. Історія соціальної педагогіки та соціальної роботи: Курс лекцій. Тернопіль : ТДПУ, 2009. $256 \mathrm{c}$.

5. Постанова КМУ "Про перелік напрямів, за якими здійснюється підготовка фахівців у вищих навчальних закладах за освітньо-кваліфікаційним рівнем бакалавра” № 1719 від 13 грудня 2006 р. [Електронний ресурс]. Режим доступу : http://zakon2.rada.gov.ua/laws/show/1719-2006-п

6. Романовська Л. І. Підготовка майбутніх соціальних педагогів до професійної діяльності та позитивні тенденції такого процесу в Україні. Збірник наукових пращь Хмельницького інституту соиіальних технологій Університету “Украӥна”. 2013. № 2 (8). С. 224-227.

7. Савельчук І. Б. Підготовка соціальних працівників за сучасних умов: інноваційні тенденції. Вісник Житомирського державного університету імені Івана Франка. Педагогічні науки. 2016. Вип. 1. C. $120-125$.

8. Соціальна робота в Україні: перші кроки. Київ : KM Academia, 2000. 236 с.

9. Фурман А. В., Підгурська М. В. Історія соціальної роботи : навчальний посібник. Тернопіль : THEУ, 2014. 174 c.

\section{Referances:}

[1] Lukashevy`ch M. P., (2009). Social’na robota (teoriya i prakty`ka) [Tekst]: Pidruchny`k [Social work (theory and practice)]. Ky`yiv : Karavela.

[2] Mishhy`k L. I., (1999). Social`na pedagogika: dosvid ta perspekty`vy`. [Social pedagogics: experience and perspectives]. Zaporizhzhia.

[3] Nakaz Ministerstva social’noyi polity`ky' Ukrayiny, (2012).' "Pro zatverdzhennya novoyi redakciyi kvalifikacijnoyi xaraktery`sty`ky" profesiyi "Faxivecz' iz social noyi roboty". [Order of the Ministry of Social Policy of Ukraine.

[4] (2012) "On Approval of new Edition of the Qualification Characteristic of Profession "Specialist in Social Work"] [Elektronny'j resurs]. Rezhy`m dostupu: http://romny-mcss.edukit.sumy.ua/Files /downloads/nakaz\%20Minsoczpolity`ky`\%20 vid\%2025.05.2012\%20\#324.doc.

[5] Polishhuk V. A. (2009). Istoriya social noyi pedagogiky` ta social noyi roboty`: Kurs lekcij. [The history of social pedagogics and social work: Course of lectures]. TDPU, Ternopil.

[6] Postanova KMU, (2006). "Pro perelik napryamiv, za yaky`my` zdijsnyuyet’sya pidgotovka faxivciv u vy`shhy`x navchal`ny`x zakladax za osvitn`o-kvalifikacijny`m rivnem bakalavra”. [Decree of the Cabinet of Ministers of Ukraine,

[7] 2006 "On the List of Directions according to which Specialists of Higher Educational Establishments are trained for the Educational Qualification Level of Bachelor"]. [Elektronny`j resurs]. Rezhy`m dostupu : http://zakon2.rada.gov.ua/laws/show/1719-2006-p.

[8] Romanovs`ka L. I., (2013). Pidgotovka majbutnix social`ny`x pedagogiv do profesijnoyi diyal'nosti ta pozy`ty`vni tendenciyi takogo procesu v Ukrayini. [Professional activity training of future social pedagogues and positive tendences of such a process in Ukraine]. Collection of scientific works of Khmelnytskyi Institute of Social Technologies of "Ukraine" University, 2 (8), p. 224-227.

[9] Savel chuk I. B., (2016). Pidgotovka social`ny`x pracivny`kiv za suchasny`x umov: innovacijni tendenciyi. [Social workers training in modern conditions: innovative trends]. Herald of Zhytomyr State University named after Ivan Franko. Pedagogic sciences 1, p. 120-125.

[10] Poltavcya V., (2000). Social na robota v Ukrayini: pershi kroky`. [Social work in Ukraine: the first steps]. Kyiv : KM Academia.

[11] Furman A. V., Pidgurs`ka M. V., (2014). Istoriya social noyi roboty`: [navchal`ny`j posibny`k]. [The history of social work]. Ternopil : TNEU, 2014. 


\section{ПАВЕЛкив К. М. Ретроспективный анализ подготовки будущих специалистов социальной сферы в Украине.}

Сегодня в мире возрастает осознание значимости сочиальной сферы в жизни отдельного человека, актуализируется сочиальная политика, возрастает потребность в сочиальной защите населения. Профессиональная подготовка специилистов социальной сферы переживает сложный период реформирования, поэтому определение правильной стратегии $в$ развитии соииальной политики, конкретных направлений и сфер соииальной работы, системь подготовки кадров для этой сферы является для Украины сегодня чрезвычайно важным вопросом. Подготовка сочиальных работников имеет свои особенности, которые обусловлены спецификой процесса становления сравнительно новой профессии в Украине, сложностью и разноплановостью деятельности, трудностями трудоустройства спечиалистов, стереотипами в отношении к специалистам сочиальной сферы.

В статье осуществлен иелостный хронологический анализ становления профессиональной подготовки будущих спещиалистов сочиальной сферы в Украине, на основе которого в этой подготовке выделены и охарактеризованы три периода: I период (1991 г. 2000 г.), II период (2001 г. - 2010 г.), III период (2011 г. - по настоящее время). Выяснено, что в каждый из определенных периодов в контексте экономических и соииальных условий профессиональная подготовка будущих спечиалистов сочиальной сферы имела свои особенности. Доказано, что изучение истории становления и развития подготовки будущих специалистов социальной сферы, критическое осмысление сочиально-педагогической практики поможет избежать ошибок на современном этапе развития компетентности специалиста и максимально творчески использовать накопленный опыт. .

Ключевые слова: будущие специалисты сочиальной сферы, социальная работа, социальный работник, сочиальный педагог, профессиональная подготовка.

\section{Ukraine. \\ PAVELKIV K. M. Retrospective analysis of future social sphere specialists' training in}

The purpose of the article is to carry out a historical analysis of formation and development of future social sphere specialists' training in Ukraine. The research methodology include approaches (system, chronological and problem, comparative), principles (historicism principle in the consideration of events and facts, the principle of logical coherence and consistency of presentation) and methods (analysis, synthesis, systematization, description, comparison, abstraction, selection of logical connections and interconnections) of obtaining new knowledge.

The result of the research is a complete chronological analysis of professional training formation of future social sphere specialists in Ukraine, on the basis of which three periods of the training have been distinguished and characterized.

For the first time it was clarified that in the context of economic and social conditions in every distinguished period professional training of future social sphere specialists had its own peculiarities: I stage (1991 - 2000) - opening a new specialty for Ukraine "Social work", active work of international organizations (Ukrainian and British and Portuguese project TEMPUS-TASIS "Social work in Ukraine", Ukrainian and Finnish and Dutch project TASIS of European Council "Social protection in Ukraine"); the creation of Association of social pedagogues and social sphere workers, opening of the first faculty of social pedagogues and workers retraining at Donetsk University, the first admission of future social workers at Zaporizhia University, Kharkiv Institute of Culture; the emergence of Ukrainian language professional literature, including periodicals, the appearance of a professional holiday - Day of social worker; II stage (2001-2010) - creation of legal and legislative basis for social work, creation of organizational and methodological conditions for the conformity of social workers training to levels of European educational system with the preservation of the structure of national system of vocational education "Junior Specialist - Bachelor - Specialist - Master"; adoption of the National Ethical Code and ratification of the Universal Declaration of Ethical Principles and Standards of Social Work; III stage (2011 - up to now) - final formation of specialty "Social work" and creation of organizational and methodological conditions for renovation of social sphere 
specialists' training according to problems of social work; formation of innovative social sphere specialists' training on the basis of competence approach.

Practical significance of the research is that the studying of the history of formation and development of future social sphere specialists' training, critical understanding of social and pedagogical practice will help to avoid mistakes at the present stage of competence development of the specialist and to use all accumulated experience in the most creative way.

Keywords: future specialists in the social sphere, social work, social worker, social teacher, vocational training.

DOI: https://doi.org/10.31392/NZ-npu-143.2019.20

УДК 378.014.

ORCID 0000-0002-8099-1566

Плющ В. М.

\section{САМОСТІЙНА РОБОТА ЯК ОДНА ІЗ ФОРМ САМООСВІТИ СТУДЕНТІВ}

Проблема самоосвіти - ие одна з педагогічних проблем, яка не втрачає своєї актуальності. Адже согодні суспільству потрібна активна, мобільна особистість, що володіє умінням планувати і самостійно організовувати власну діяльність, адекватно оиінювати якість і рівень результатів власної роботи, розширювати освітній простір для вирішення поставлених завдань та иілей. Ці якості відображаються в інтегрованій характеристиці властивостей особистості, яка виявляється в потребі, готовності $і$ здатності до самостійної освітньої діяльності.

У статті проаналізовано основні підходи до визначення понять “самоосвіта” та “самостійна робота". Здійснено аналіз співвідношення окреслених понять, який показав, щуо це два складних види діяльності, які можуть бути пов'язані між собою або збігатися один з одним окремими компонентами, зсув ијих понять може привести до неправильного вибору форм, засобів і методів їх практичної реалізаиії. Самостійну роботу слід розглядати лише як необхідну складову прочесу самоосвіти, вона формує готовність до самоосвіти, створює основу для можливості здійснення безперервної освіти та постійного підвищення своєї кваліфікачії. Оскільки прочес самоосвіти відбувається під час самостійної роботи студентів, ми можемо відзначити, що самоосвіту можна вважати метою і результатом діяльності, а самостійну роботу - засобом досягнення результату. Наголошено, щяо в умовах сьогодення самостійна робота не забезпечує якісну реалізацію поставлених перед нею завдань оскільки має недостатню цілеспрямованість, проблемність, навчально-методичне і технічне забезпечення, слабку контрольованість, недостатню диференційованість і варіативність.

Ключові слова: освіта, самоосвіта, самостійна робота студентів.

Сьогодні суспільству потрібна активна, мобільна особистість, що володіє умінням планувати і самостійно організовувати власну діяльність, адекватно оцінювати якість і рівень результатів власної роботи, розширювати освітній простір для вирішення поставлених завдань та цілей. Ці якості відображаються в інтегрованій характеристиці властивостей особистості, яка виявляється в потребі, готовності і здатності до самостійної освітньої діяльності. Необхідно зазначити, що 